\title{
Synthesis, structure and properties of lithium-ion conducting lanthanum niobates with defect perovskite structure
}

\author{
Anatolii G. BELOUS ${ }^{1 *}$, Oksana N. GAVRILENKO ${ }^{1}$, Sofiya D. KOBILYANSKAYA ${ }^{1}$, Oleg I. V'YUNOV ${ }^{1}$, \\ Volodymyr V. TRACHEVSKII ${ }^{2}$, Odile BOHNKE ${ }^{3}$ \\ ${ }^{1}$ V.I. Vernadskii Institute of General and Inorganic Chemistry of the Ukrainian NAS, \\ Palladina Ave 32-34, 03680 Kyiv 142, Ukraine \\ ${ }^{2}$ S.V. Kurdyumov Institute of Metal Physics of the Ukrainian NAS, \\ Vernadskogo Blvd. 36, 03680 Kyiv 142, Ukraine \\ ${ }^{3}$ Laboratoire des Oxydes et Fluorures (UMR6010 CNRS), Institut de Recherche en Ingénierie \\ Moléculaire et Matériaux Fonctionnels (FR 2575 CNRS), Université du Maine, \\ O. Messiaen Ave, 72085 Le Mans Cedex 9, France \\ * Corresponding author. Tel./fax: +380-44-424-22-11; e-mail: belous@ionc.kar.net
}

Received May 30, 2010; accepted October 29, 2010; available on-line March 2, 2011

Solid solutions with defect perovskite structure have been obtained in the system $\operatorname{Li}_{0.5-y} N_{y} \operatorname{La}_{0.5} \square \mathrm{Nb}_{2} \mathrm{O}_{6}$ at $0 \leq y \leq 0.5$. It has been shown that when sodium ions substitute for lithium ions, an increase in the unit cell volume of the defect perovskite is observed. The existence of lithium ions with different mobility in the system $\mathrm{Li}_{0.5-\mathrm{y}} \mathrm{Na}_{\mathrm{y}} \mathrm{La}_{0.5} \square \mathrm{Nb}_{2} \mathrm{O}_{6}(0 \leq y<0.5)$ has been shown by ${ }^{7} \mathrm{Li} \mathrm{NMR}$. A percolation mechanism of the $\mathrm{Li}$ ion diffusion is not observed in this system. The lithium-ion conductivity in $\mathrm{Li}_{0.5-\mathrm{y}} \mathrm{Na}_{\mathrm{y}} \mathrm{La}_{0.5} \square \mathrm{Nb}_{2} \mathrm{O}_{6}($ at $y \leq 0.43)$ is higher in comparison with $\mathrm{La}_{0.5} \mathrm{Li}_{0.5} \mathrm{Nb}_{2} \mathrm{O}_{6}$. This may be due both to the increased amount of more mobile $\mathrm{Li}^{+}$ ions in the sodium-substituted samples and to the increase of the cell volume. The lithium-containing lanthanum niobate $\mathrm{La}_{0.5} \mathrm{Li}_{0.5} \mathrm{Nb}_{2} \mathrm{O}_{6}$ has been obtained by the Pechini method. It has been shown that the resistance of this sample is lower than that of a sample of the same composition prepared by the solid-state reaction method.

Sodium-containing lithium-lanthanum niobate/ Lithium ion mobility / Ionic transport / ${ }^{7}$ Li NMR / Pechini method

\section{Introduction}

Lithium-ion conducting solid electrolytes are of interest due to the possibility of obtaining on their basis materials with high ionic conductivity for electrochemical devices [1]. Materials based on $\mathrm{Li}_{3 x} \mathrm{La}_{2 / 3-x} \square_{4 / 3-2 x} \mathrm{Nb}_{2} \mathrm{O}_{6}$ with defect perovskite structure contain a considerable number of vacancies and channels for lithium ion migration. This fact allowed us to obtain materials with high lithium-ion conductivity values $\left(\sigma \sim 10^{-4}-10^{-5} \mathrm{~S} \mathrm{~cm}^{-1}\right.$ at $\left.290 \mathrm{~K}\right)$ in the $\mathrm{Li}_{0.5-y} \mathrm{Na}_{y} \mathrm{La}_{0.5} \square \mathrm{Nb}_{2} \mathrm{O}_{6}$ system [2-6]. When the samples are synthesized by the solid-state reaction (SSR) method, coarse-grained powders are formed [4]. It is known from literature that when the particle size of a lithium-ion conducting electrolyte is reduced, the cycle life of electrochemical power sources increases [7]. Precipitation from a solution allows synthesizing $\mathrm{La}_{0.5} \mathrm{Li}_{0.5} \mathrm{Nb}_{2} \mathrm{O}_{6}$ with particles of smaller size [8]. However, the product is not homogeneous since it is impossible to obtain insoluble lithium precipitates. At the same time, the Pechini method, which is employed in the synthesis of many functional materials, allows obtaining nanosized particles and homogenizing the mixture at the molecular level [9].

We have shown $[3,5]$ that one of the main factors that determines the ionic conductivity $(\sigma)$ in $\mathrm{Li}_{3 x} \mathrm{La}_{2 / 3-x} \square_{4 / 3-2 x} \mathrm{Nb}_{2} \mathrm{O}_{6}$ is the structural factor. In particular, migration of $\mathrm{Li}$ ions is limited by the area of the bottleneck formed by four adjacent oxygen octahedra [10] (Fig. 1). The size of the structural channel is dependent on the radius of the ions of the perovskite $A$-sublattice (Fig. 1). It has been shown [11-14] that partial or complete replacement of the $\mathrm{La}^{+3}\left(r_{\mathrm{CN} 12}=1.32 \AA\right)$ and $\mathrm{Li}^{+}$ions $\left(r_{\mathrm{CN} 6}=0.74 \AA\right)$ in the perovskites by ions of larger size, $\mathrm{Sr}^{+2}\left(r_{\mathrm{CN} 12}=\right.$ $1.44 \AA$ ), increases the ionic conductivity of these materials. Interesting results were obtained by substituting $\mathrm{Na}^{+}$ions $\left(r_{\mathrm{CN} 6}=1.02 \AA\right)$ for $\mathrm{Li}^{+}$ions in the system $\mathrm{Li}_{3 x} \mathrm{La}_{2 / 3-x} \square_{1 / 3-2 x} \mathrm{TiO}_{3}$ [15-16]. At $y>0.2$, a percolation mechanism of the lithium conductivity was observed. This manifests itself by a rapid decrease in conductivity caused by blocking of lithium ion migration paths by $\mathrm{Na}^{+}$ions. It has been shown by 




Fig. 1 Structure of the $A$-site deficient perovskite $\quad \mathrm{La}_{2 / 3} \square_{4 / 3} \mathrm{Nb}_{2} \mathrm{O}_{6} \quad$ (space group Pmmm): La in position $1 a(000), \mathrm{Nb}$ in $2 t$ $\left(1 / 2 \frac{1}{2} \quad z\right), \mathrm{O}(1)$ in $1 f(1 / 2 \quad 1 / 20), \mathrm{O}(2)$ in $1 h$ $\left(1 / 2 \frac{1}{2} \frac{1}{2}\right), \mathrm{O}(3)$ in $2 s(1 / 20 z), \mathrm{O}(4)$ in $2 r\left(0 \frac{1}{2} z\right)$, and vacancies in $1 c\left(\begin{array}{lll}0 & 0 & 1 / 2\end{array}\right)$.

neutron diffraction studies and NMR spectroscopy that $\mathrm{Li}^{+}$moves to the centers of the unit cell faces, whereas the $\mathrm{Na}^{+}$and $\mathrm{La}^{+3}$ ions are located at the center of the unit cell $[15,16]$. The existence of lithium ions with different mobility has also been shown $[17,18]$.

In the $\mathrm{Li}_{3 x} \mathrm{La}_{2 / 3-x} \square_{4 / 3-2 x} \mathrm{Nb}_{2} \mathrm{O}_{6}$ system, the number of vacancies is much larger than in the titanates. Extra vacancies exist owing to the presence of planes in the structure that are completely free from $\mathrm{La}^{+3}$ ions (Fig. 1). This allows assuming that the mechanism of lithium ion diffusion in niobates differs from that in titanates. In $[19,20]$ an increase of the unit cell volume of $\mathrm{La}_{x} \mathrm{Li}_{0.5-y} \mathrm{Na}_{y} \square \mathrm{Nb}_{2} \mathrm{O}_{6}$ samples and of the ionic conductivity with increasing $\mathrm{Na}^{+}$content was observed. In these works the $\mathrm{Na}^{+}$ions were found to substitute both for $\mathrm{Li}^{+}$ions and for $\mathrm{La}^{+3}$ ions. In this case, in order to maintain electroneutrality, the number of vacant positions ( $\square$ ) decreases. Besides, since the ionic radius of $\mathrm{Na}^{+}$is smaller than that of $\mathrm{La}^{+3}$, the substitution for lanthanum can lead to a decrease of the unit cell volume $(V)$ of the perovskite. Therefore, isovalent substitution of $\mathrm{Na}^{+}$ions only for $\mathrm{Li}^{+}$ions in the system of lithium-ion conducting lanthanum niobates is preferable for the preparation of lithiumcontaining materials.

The aim of this work was to prepare lithiumcontaining materials of the $\mathrm{Li}_{0.5-y} \mathrm{Na}_{y} \mathrm{La}_{0.5} \square \mathrm{Nb}_{2} \mathrm{O}_{6}$ system $(0.0 \leq y \leq 0.5)$ and to investigate their structure and ionic conductivity.

\section{Experimental}

$\mathrm{Li}_{0.5-y} \mathrm{Na}_{y} \mathrm{La}_{0.5} \mathrm{Nb}_{2} \mathrm{O}_{6}$ samples $(y=0.0,0.1,0.2,0.3$, $0.4,0.43,0.46,0.48,0.5)$ were synthesized by the solid-state reaction technique (SSR). High-purity $\mathrm{La}_{2} \mathrm{O}_{3}, \mathrm{Nb}_{2} \mathrm{O}_{5}, \mathrm{Li}_{2} \mathrm{CO}_{3}$, and $\mathrm{Na}_{2} \mathrm{CO}_{3}$ were used as initial reagents. The synthesis procedure is described in detail in $[3,5]$. The samples were pressed and calcined at $970 \mathrm{~K}$ for $4 \mathrm{~h}$. After grinding, they were calcined at $1320 \mathrm{~K}$ (time $2 \mathrm{~h}$ ). Sintering was carried out at $1470-1550 \mathrm{~K}$ (time $2 \mathrm{~h}$ ). The density of the ceramics was $4.88-5.05 \mathrm{~g} / \mathrm{cm}^{3}$. The density of the sintered samples ranged from 94 to $99 \%$, depending on the sample.

To determine the effect of the method of synthesis on the ionic conductivity, a $\mathrm{Li}_{0.5-y} \mathrm{Na}_{y} \mathrm{La}_{0.5} \square \mathrm{Nb}_{2} \mathrm{O}_{6}$ sample $(y=0)$ was also synthesized by the Pechini method. In the Pechini method, the crystalline hydrates $\mathrm{LiNO}_{3} \cdot 3 \mathrm{H}_{2} \mathrm{O}$ and $\mathrm{La}\left(\mathrm{NO}_{3}\right)_{3} \cdot 6 \mathrm{H}_{2} \mathrm{O}$, and $\mathrm{NbCl}_{5}$ (all chemical-purity grade) were used as initial reagents. Niobium chloride was dissolved in isopropyl alcohol (chemical-purity grade $\mathrm{iPrOH}$ ). Citric acid (chemical-purity grade CA) and excess ethylene glycol (chemical-purity grade EG) were added to the resulting solution. $\mathrm{CA}$ was also added to aqueous solutions of $\mathrm{LiNO}_{3} \cdot 3 \mathrm{H}_{2} \mathrm{O}$ and $\mathrm{La}\left(\mathrm{NO}_{3}\right)_{3} \cdot 6 \mathrm{H}_{2} \mathrm{O}$. The solutions were mixed in stiochiometric ratios and heated at $340 \mathrm{~K}$ under stirring. To obtain a xerogel, the polymer was calcined additionally at $370 \mathrm{~K}$ for $12 \mathrm{~h}$. Precursor powder (LLNbO) was prepared by calcining the polymer at $570 \mathrm{~K}$. The powder was pressed and fired at $1270 \mathrm{~K}$ (time $2 \mathrm{~h}$ ). Sintering was carried out at $1520 \mathrm{~K}$ for $2 \mathrm{~h}$. The density of the ceramic was $4.95 \mathrm{~g} / \mathrm{cm}^{3}$ (98\% of the crystallographic value).

The phases were identified by X-ray powder diffraction (XRD) recorded at room temperature with a DRON-4-07 diffractometer $(\mathrm{Cu} \mathrm{K \alpha}$ radiation, $40 \mathrm{kV}, 18 \mathrm{~mA})$. Data for sintered samples were collected in the $2 \theta$ range from 10 to $150^{\circ}$ in a step mode with the step $\Delta 2 \theta=0.02^{\circ}$ and an exposure time of $6 \mathrm{~s}$ for each point. The crystal parameters were refined by Rietveld full-profile analysis.

The electrophysical properties of the ceramic samples were investigated by complex impedance spectroscopy in the frequency range from $1 \mathrm{~Hz}$ to $5 \mathrm{MHz}$ using a Solartron 1260 Frequency Gain-Rhase Analyzer coupled with a 1296 Dielectric Interface. Sputtered Pt was used as ion-blocking electrodes. To gain insight into the charge-transport mechanism, the electrical conductivity $(\sigma)$ was measured as a function of temperature and frequency in special cells that enable $\sigma$ measurements in vacuum, air, and inert atmospheres. Electrical contacts were made by firing silver paste. The specimens were $0.9 \pm 0.1 \mathrm{~cm}$ in diameter and $0.3 \pm 0.2 \mathrm{~cm}$ in thickness. The total 
A.G. Belous et al., Synthesis, structure and properties of lithium-ion conducting lanthanum niobates ...

Table 1 Structure parameters of complex oxides in the system $\mathrm{Li}_{0.5-y} \mathrm{Na}_{y} \mathrm{La}_{0.5} \square \mathrm{Nb}_{2} \mathrm{O}_{6}$ as a function of the sodium content (y). Space group Pmmm, for atom positions see Fig. 1.

\begin{tabular}{|c|c|c|c|c|c|c|c|c|}
\hline$y$ & 0.1 & 0.2 & 0.3 & 0.4 & 0.43 & 0.46 & 0.48 & 0.5 \\
\hline \multicolumn{9}{|c|}{ Unit cell parameters } \\
\hline$a, \AA$ & $3.903(8)$ & $3.906(8)$ & $3.915(1)$ & $3.915(9)$ & $3.923(1)$ & $3.918(1)$ & $3.9167(8)$ & $3.925(1)$ \\
\hline$b, \AA$ & $3.904(7)$ & $3.907(8)$ & $3.912(1)$ & $3.915(9)$ & $3.9311(6)$ & $3.923(1)$ & $3.9304(7)$ & $3.9278(6)$ \\
\hline$c, \AA$ & $7.854(2)$ & $7.852(1)$ & 7.861(1) & $7.861(1)$ & $7.850(2)$ & $7.860(2)$ & $7.846(2)$ & $7.848(3)$ \\
\hline$V, \AA^{3}$ & 119.7(3) & $119.8(4)$ & $120.40(5)$ & $120.5(2)$ & $121.07(5)$ & $120.79(6)$ & $120.78(4)$ & $120.98(6)$ \\
\hline \multicolumn{9}{|c|}{ Atom coordinates } \\
\hline $\mathrm{Nb}, z / c$ & $0.254(2)$ & $0.256(1)$ & $0.256(1)$ & $0.259(1)$ & $0.2527(8)$ & $0.2551(9)$ & $0.2582(9)$ & $0.251(1)$ \\
\hline $\mathrm{O} 3, z / c$ & $0.24(2)$ & $0.30(4)$ & $0.26(2)$ & $0.3(3)$ & $0.28(1)$ & $0.26(4)$ & $0.260(6)$ & $0.29(4)$ \\
\hline $\mathrm{O} 4, z / c$ & $0.21(2)$ & $0.28(4)$ & $0.29(2)$ & $0.3(3)$ & $0.29(1)$ & $0.26(4)$ & $0.272(7)$ & $0.28(4)$ \\
\hline \multicolumn{9}{|c|}{ Agreement factors } \\
\hline $\mathrm{R}_{\mathrm{f}}, \%$ & 6.42 & 6.98 & 5.92 & 5.36 & 7.36 & 6.30 & 5.94 & 6.40 \\
\hline $\mathrm{R}_{\exp }, \%$ & 8.62 & 9.15 & 9.78 & 8.36 & 5.01 & 4.84 & 4.18 & 8.96 \\
\hline
\end{tabular}

conductivity was found to be comprised of hole, electronic, and ionic contributions. The electronic conductivity was measured at a dc voltage of $0.5 \mathrm{~V}$, which was low enough to rule out electrolysis. At $570 \mathrm{~K}$, the electronic contribution was no greater than $0.05 \%$ of the total conductivity. In evaluating the lithium-ion conductivity, we took into account the blocking contacts and interfacial polarization effects.

${ }^{7} \mathrm{Li}$ NMR spectra were recorded on an AVANCE 400 spectrometer (Bruker, Germany) at frequencies of $155.51 \mathrm{MHz}$ and $105.84 \mathrm{MHz}$ in the temperature range $235-350 \mathrm{~K}$. The chemical shift of resonating lines is given with respect to $\mathrm{Li}\left(\mathrm{H}_{2} \mathrm{O}\right)_{4}{ }^{+} \mathrm{Cl}^{-}$signals. The profile function parameters of the NMR spectra (wide Gaussian and narrow Lorenzian components) were determined using a PeakFit software. The ${ }^{7} \mathrm{Li}$ MAS-NMR spectra were registered using $4 \mathrm{~mm} \mathrm{ZrO}_{2}$ sample rotors and rotation speed $10 \mathrm{kHz}$.

\section{Results and discussion}

System $\mathrm{Li}_{0.5-\mathrm{y}} \mathrm{Na}_{\mathrm{y}} \mathrm{La}_{0.5} \square \mathrm{Nb}_{2} \mathrm{O}_{6}$

The XRD results for the $\mathrm{Li}_{0.5-y} \mathrm{Na}_{y} \mathrm{La}_{0.5} \square \mathrm{Nb}_{2} \mathrm{O}_{6}$ ceramics (Fig. 2) showed the formation of singlephase materials with defect-perovskite structure of the orthorhombic system (space group Pmmm) in the range $0 \leq y \leq 0.5$. In the studied range of isovalent substitutions there is a superstructure reflection 101, which indicates additional ordering of structural vacancies [21] in the plane $z=1 / 2$ (Fig. 1). The intensity of the 101 reflection decreases with increasing $y$, which probably indicates a substitution of sodium ions for lithium ions both in the plane $z=0$ and in the plane $z=1 / 2$, causing structural disorder (Figs. 1,2).

Table 1 lists structure parameters of the $\mathrm{Li}_{0.5-y} \mathrm{Na}_{y} \mathrm{La}_{0.5} \square \mathrm{Nb}_{2} \mathrm{O}_{6}$ ceramics. The coordinates in the structure of $\mathrm{Li}_{3 x} \mathrm{La}_{2 / 3-x} \square_{4 / 3-2 x} \mathrm{Nb}_{2} \mathrm{O}_{6}$ [21] were used as starting model. The unit cell volume increases with increasing $y$ in accordance with Vegard's law.

It has been shown that the large sodium ions cannot participate in ionic transport in the $\mathrm{Li}_{0.5-y} \mathrm{Na}_{y} \mathrm{La}_{0.5} \square \mathrm{Nb}_{2} \mathrm{O}_{6}$ system $[15,16]$. The motion of $\mathrm{Li}^{+}$ions alone determines the ionic conductivity. Fig. 3(a) shows an Arrhenius plot of the total conductivity (bulk + grain boundary) for different sodium concentrations. The conductivity was derived from impedance data using the equivalent circuit model. The concentration dependencies of the electrical conductivity and activation energy $\left(E_{\mathrm{a}}\right)$ of the $\mathrm{Li}_{0.5-\mathrm{y}} \mathrm{Na}_{\mathrm{y}} \mathrm{La}_{0.5} \square \mathrm{Nb}_{2} \mathrm{O}_{6}$ samples were calculated. Isotherms of electrical conductivity against the amount of lithium are shown in Fig. 3(b). When sodium was substituted for lithium in the system $\mathrm{Li}_{0.5-y} \mathrm{Na}_{y} \mathrm{La}_{0.5} \square \mathrm{Nb}_{2} \mathrm{O}_{6}$, the value of the ionic

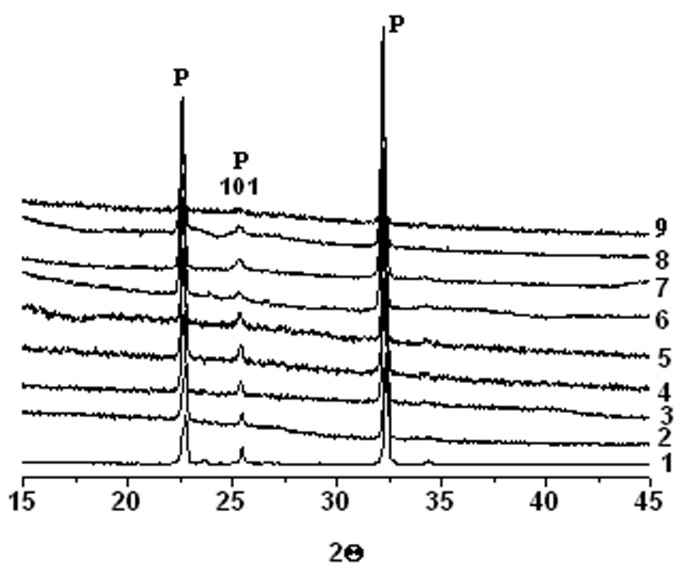

Fig. 2 X-ray diffraction patterns of sintered $\mathrm{Li}_{0.5-y} \mathrm{Na}_{y} \mathrm{La}_{0.5} \square \mathrm{Nb}_{2} \mathrm{O}_{6}$ samples with different sodium concentrations: (1) $y=0$; (2) $y=0.1$; (3) $y=0.2$; (4) $y=0.3$; (5) $y=0.4$; (6) $y=0.43$; (7) $y=0.46$; (8) $y=0.48$; (9) $y=0.5$. 


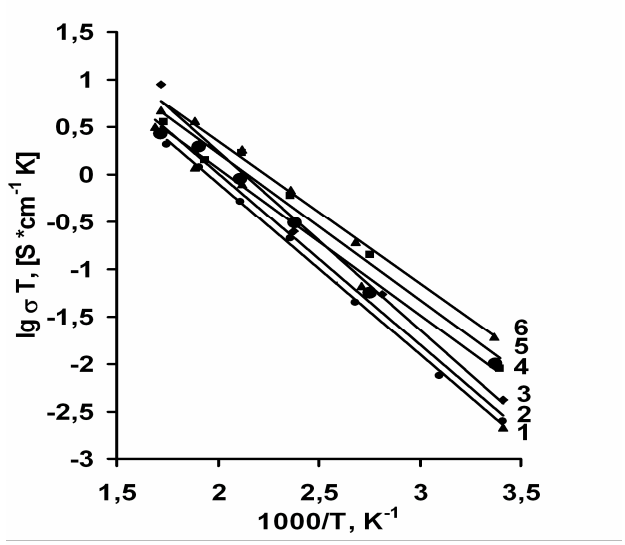

a

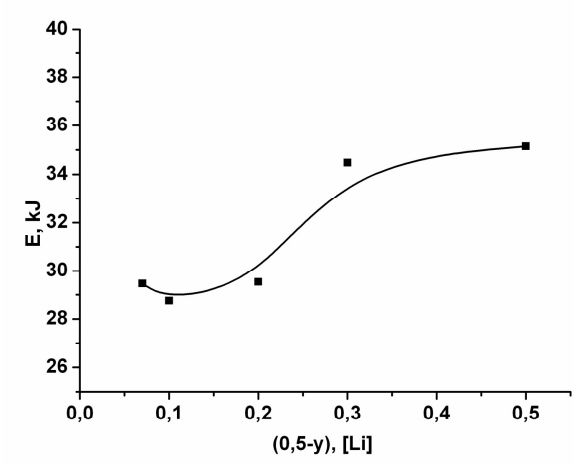

c

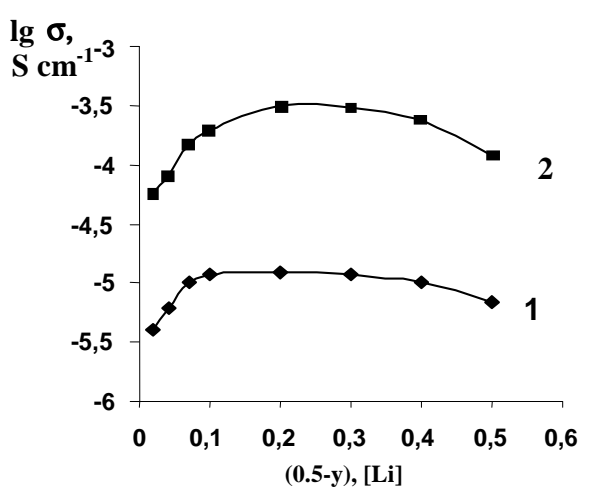

b

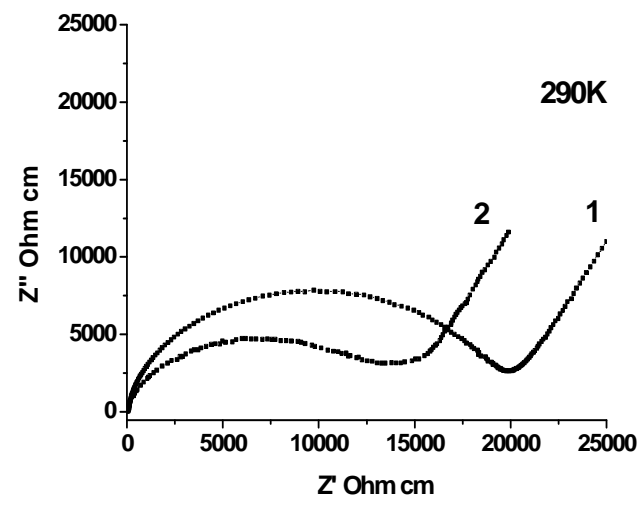

d

Fig. 3 Electrophysical properties of the system $\mathrm{Li}_{0.5-y} \mathrm{Na}_{y} \mathrm{La}_{0.5} \square \mathrm{Nb}_{2} \mathrm{O}_{6}$. (a) Arrhenius plots of the total ionic conductivity of sintered pellets of $\mathrm{Li}_{0.5-y} \mathrm{Na}_{y} \mathrm{La}_{0.5} \square \mathrm{Nb}_{2} \mathrm{O}_{6}$ with various sodium concentrations: (1) $y=0$; (2) $y=0.2$; (3) $y=0.3$; (4) $y=0.4$; (5) $y=0.43$; (6) $y=0.46$. (b) Isotherms of ionic electrical conductivity as a function of the lithium concentration [Li] in the system $\mathrm{Li}_{0.5-y} \mathrm{Na}_{y} \mathrm{La}_{0.5} \square \mathrm{Nb}_{2} \mathrm{O}_{6}$ at various temperatures: (1) $290 \mathrm{~K}$; (2) $370 \mathrm{~K}$. (c) Activation energy of conductivity ( $E_{\mathrm{a}}$ ) of $\mathrm{Li}_{0.5-y} \mathrm{Na}_{\mathrm{y}} \mathrm{La}_{0.5} \square \mathrm{Nb}_{2} \mathrm{O}_{6}$ as a function of the lithium concentration [Li]. (d) Plots of complex impedance of samples $\mathrm{Li}_{0.5-y} \mathrm{Na}_{y} \mathrm{La}_{0.5} \square \mathrm{Nb}_{2} \mathrm{O}_{6} \quad(y=0)$ prepared by the SSR method (1) and the Pechini method (2). $T=290 \mathrm{~K}$.

conductivity at $290 \mathrm{~K}$ increased from $\sigma=6.8510^{-6} \mathrm{~S} \mathrm{~cm}^{-1}$ at $y=0$ to $\sigma=1.2810^{-5} \mathrm{~S} \mathrm{~cm}^{-1}$ at $y=0.43$. Further increase of $y(y>0.43)$ led to a sharp decrease of $\sigma$. In the case when sodium was substituted for lithium, the activation energy of conductivity decreased (Fig. 3(c)).

An analysis of the dependencies shown in Fig. 3(b,c) allowed us to conclude that the ionic conductivity in the system $\mathrm{Li}_{0.5-y} \mathrm{Na}_{y} \mathrm{La}_{0.5} \square \mathrm{Nb}_{2} \mathrm{O}_{6}$ is affected by two competing factors depending on $y$. On the one hand, when $y$ is increased $V$ increases (Table 1), which produces an increase of $\sigma$ and a decrease of $E_{\mathrm{a}}$. On the other hand, increasing the $\mathrm{Na}^{+}$ concentration leads to a decrease of the charge carrier (lithium) concentration and hence to a decrease of the conductivity. As a result of these two competing effects, the concentration dependence of the lithiumion conductivity exhibits a maximum.
Fig. 3(d) shows the complex impedance of $\mathrm{Li}_{0.5-y} \mathrm{Na}_{y} \mathrm{La}_{0.5} \square \mathrm{Nb}_{2} \mathrm{O}_{6} \quad$ samples with $y=0$ $\left(\mathrm{Li}_{0.5} \mathrm{La}_{0.5} \mathrm{Nb}_{2} \mathrm{O}_{6}\right)$, obtained by the SSR method and the Pechini method. We can see that the impedance of the sample prepared by the Pechini method is smaller than that of the sample prepared by the solid-state reaction technique. This can be explained by the fact that samples synthesized by the Pechini method have higher chemical homogeneity, greater density (the density of the sintered samples obtained from the SSR and the Pechini method was 95 and $98 \%$, respectively), and larger cell volume, as compared to the sample synthesized by SSR (Table 2).

${ }^{7} \mathrm{Li}$ NMR spectra of the samples in the system $\mathrm{Li}_{0.5-y} \mathrm{Na}_{y} \mathrm{La}_{0.5} \square \mathrm{Nb}_{2} \mathrm{O}_{6}$ as a function of the sodium concentration were obtained (Fig. 4(a,b)). The displacement of NMR lines $(\delta)$ to stronger fields with increasing temperature for $y=0.2$ and $y=0$ 
A.G. Belous et al., Synthesis, structure and properties of lithium-ion conducting lanthanum niobates ...

Table 2 Structure parameters of $\mathrm{Li}_{0.5} \mathrm{La}_{0.5} \mathrm{Nb}_{2} \mathrm{O}_{6}$ samples obtained by two methods of synthesis. Space group Pmmm, for atom positions see Fig. 1.

\begin{tabular}{|c|c|c|}
\hline Method of synthesis & SSR & Pechini method \\
\hline \multicolumn{3}{|c|}{ Unit cell parameters } \\
\hline$a, \AA$ & $3.9002(1)$ & $3.903(1)$ \\
\hline$b, \AA$ & $3.9005(1)$ & $3.908(1)$ \\
\hline$c, \AA$ & $7.8521(2)$ & $7.868(6)$ \\
\hline$V, \AA^{3}$ & $119.4521(6)$ & $120.01(6)$ \\
\hline \multicolumn{3}{|c|}{ Atom coordinates } \\
\hline $\mathrm{Nb}, z / c$ & $0.2580(2)$ & $0.259(1)$ \\
\hline $\mathrm{O} 3(\mathrm{O} 4), z / c$ & $0.23(1)$ & $0.230(6)$ \\
\hline \multicolumn{3}{|c|}{ Agreement factors } \\
\hline $\mathrm{R}_{\mathrm{B}}, \%$ & 8.5 & 8.10 \\
\hline $\mathrm{R}_{\mathrm{f}}, \%$ & 9.2 & 9.19 \\
\hline
\end{tabular}

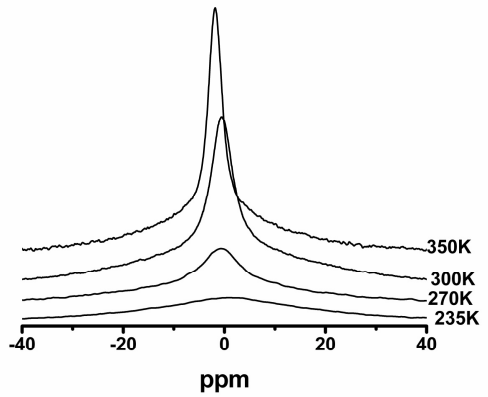

a

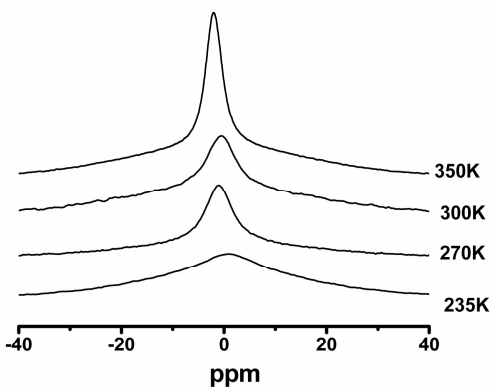

b

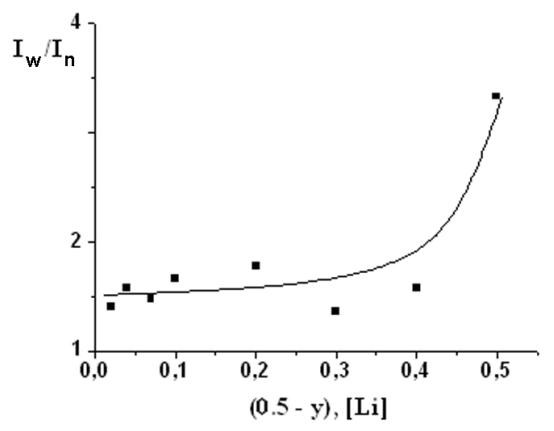

C

Fig. $4{ }^{7} \mathrm{Li}$ NMR spectra of the system $\mathrm{Li}_{0.5-y} \mathrm{Na}_{y} \mathrm{La}_{0.5} \mathrm{Nb}_{2} \mathrm{O}_{6}$ : (a) $y=0.2$; (b) $y=0$; (c) ratio of intensity of the wide and narrow components $\left(I_{w} / I_{n}\right) . T=290 \mathrm{~K}$.

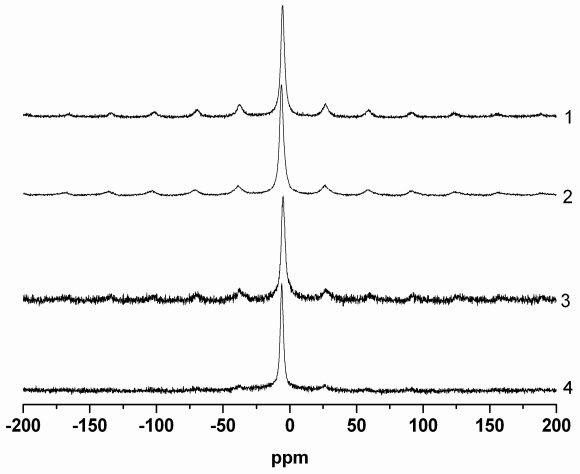

Fig. $5 \quad{ }^{7} \mathrm{Li} \quad$ MAS-NMR spectra of $\mathrm{Li}_{0.5-y} \mathrm{Na}_{y} \mathrm{La}_{0.5} \mathrm{Nb}_{2} \mathrm{O}_{6}$ for various sodium concentrations: 1) $y=0$; 2) $y=0.4$; 3) $y=0.43$; 4) $y=0.48 . T=290 \mathrm{~K}$.

(Fig. 4(a,b)) indicates that the action of the field produced by the ions of the near environment is enhanced (higher degree of screening of the lithium nuclei) with increasing $\sigma$. The narrowing of lines, which occurs in this case, is connected with an increase of the ionic conductivity with increasing temperature. The NMR spectra of all the investigated samples were a superposition of wide $\left(I_{w}\right)$ and narrow $\left(I_{n}\right)$ components. The presence of two components is accounted for by considering the arrangement of the lithium ions, which are located in different planes $(z=0, z=1 / 2)$ and have different near environment (Fig. 1) and, obviously, different mobility [16-18]. The wide component corresponds to the presence of less mobile lithium ions, whereas the narrow component can be assigned to the presence of more mobile lithium ions. The decrease in the ratio $I_{w} / I_{n}$ with the substitution of sodium ions for lithium ions (Fig. 4(c)) indicates an increase of the proportion of more mobile ions, which may be due to an increase of the unit cell volume of the perovskite.

The presence of two types of lithium ion with different mobility is also evidenced by the ${ }^{7} \mathrm{Li} \mathrm{NMR}$ spectra of the samples of the $\mathrm{Li}_{0.5-y} \mathrm{Na}_{y} \mathrm{La}_{0.5} \square \mathrm{Nb}_{2} \mathrm{O}_{6}$ 
system in the case of sample rotation around a magic angle (MAS-NMR, Fig. 5). Since ${ }^{7} \mathrm{Li}$ has a nuclear spin $I=3 / 2$, the spectra are formed by a central $(-1 / 2$, $1 / 2)$ and two satellite transitions, $(1 / 2,3 / 2)$ and $(-1 / 2$, $-3 / 2)$. These components are modulated by equally spaced bands. The more intense central line forms the NMR spectra of the more mobile lithium ions, whereas the satellite lines form the spectra of the less mobile lithium ions. Fig. 5 shows that the intensity of the lines connected with the localized (inside in the cell) motion of lithium ions decreases with increasing $y$. This indicates an increase of the part of more mobile lithium ions in sodium-rich samples.

In the $\mathrm{Li}_{0.5-y} \mathrm{Na}_{y} \mathrm{La}_{0.5} \square \mathrm{Nb}_{2} \mathrm{O}_{6}$ system, as in the $\mathrm{Li}_{0.5-x} \mathrm{Na}_{x} \mathrm{La}_{0.5} \mathrm{TiO}_{3}$ system $[17,18]$, the presence of two types of lithium ion with different mobility is observed. However, a considerable difference between titanates and niobates is noteworthy. The isovalent substitution of sodium ions for lithium ions in $\mathrm{Li}_{0.5} \mathrm{La}_{0.5} \mathrm{TiO}_{3}$ causes blocking of lithium-ion migration channels above a certain $\mathrm{Na}^{+}$concentration and a percolation mechanism of the lithium ion diffusion [15-18]. In the $\mathrm{Li}_{0.5-y} \mathrm{Na}_{y} \mathrm{La}_{0.5} \square \mathrm{Nb}_{2} \mathrm{O}_{6}$ system, solid solutions with perovskite structure are formed in the whole concentration range, and an increase of the ionic conductivity in comparison with $\mathrm{Li}_{0.5} \mathrm{La}_{0.5} \mathrm{Nb}_{2} \mathrm{O}_{6}$ is observed. This difference occurs for several reasons. The first one is the much larger number of vacancies in niobates in comparison with titanates. The second one is the increase of the size of the migration channels with increasing sodium content. This contributes to a decrease of the activation energy of ionic conductivity in the $\mathrm{Li}_{0.5-y} \mathrm{Na}_{y} \mathrm{La}_{0.5} \square \mathrm{Nb}_{2} \mathrm{O}_{6}$ system.

The question concerning the distribution of lithium ions with different mobility over the crystallographic positions and the diffusion in $\mathrm{Li}_{0.5-y} \mathrm{Na}_{y} \mathrm{La}_{0.5} \square \mathrm{Nb}_{2} \mathrm{O}_{6}$ calls for more detailed studies.

\section{Conclusions}

The formation of a solid solution with defect perovskite structure has been established in the system $\mathrm{Li}_{0.5-y} \mathrm{Na}_{y} \mathrm{La}_{0.5} \square \mathrm{Nb}_{2} \mathrm{O}_{6}$ at $0.0 \leq y \leq 0.5$, and its structure has been studied. It has been shown that when sodium ions substitute for lithium ions, an increase in the unit cell volume $(V)$ of the defect perovskite is observed. The ionic conductivity $v s . \mathrm{Li}^{+}$ content passes through a maximum as a result of two competing factors: increase of the unit cell volume and decrease of the lithium-ion concentration. The existence of lithium ions with different mobility in the $\mathrm{Li}_{0.5-y} \mathrm{Na}_{y} \mathrm{La}_{0.5} \square \mathrm{Nb}_{2} \mathrm{O}_{6}$ system $(0 \leq y<0.5)$ and their role in the ionic transport has been shown by the NMR method. Lithium-containing lanthanum niobate $\mathrm{Li}_{0.5} \mathrm{La}_{0.5} \square \mathrm{Nb}_{2} \mathrm{O}_{6}(y=0)$ has been obtained by the Pechini method. It has been shown that the resistance of this sample is less than that of the corresponding sample prepared by the solid-state reaction technique.

\section{References}

[1] Ye.I. Burmakin, Solid Electrolytes with Alkali Metal Ion Conductivity, Nauka, Moskow, 1992, p. 263 (in Russian).

[2] A. Belous, I. Didukh, E. Novosadova, Y. Pashkova, Fiz. Tverd. Tela 28 (1986) 3230-3232.

[3] A.G. Belous, O.N. Gavrilenko, E.V. Pashkova, V.N. Mirnyi, Elektrokhim. 38 (2002) 479-484.

[4] O.N. Gavrilenko, E.V. Pashkova, B.S. Khomenko, A.G. Belous, Ukr. Khim. Zh. 69 (2003) 67-71.

[5] A. Belous, E. Pashkova, O. Gavrilenko, O. V'yunov, L. Kovalenko, J. Eur. Ceram. Soc. 24 (2004) 1301-1304.

[6] A.G. Belous, O.N. Gavrilenko, E.V. Pashkova, K.P. Danil'chenko, O.I. V'yunov, Neorg. Mater. 40 (2004) 993-1000.

[7] J. Jamnikab, J. Maier, Phys. Chem. Chem. Phys. 5 (2003) 5215-5220.

[8] A. Belous, O. Gavrilenko, O. Pashkova, O. Bohnké, C. Bohnké, Eur. J. Inorg. Chem. (2008) 4792-4796.

[9] M.P. Pechini, Method of Preparing Lead and Alkaline Earth Titanates and Niobates and Coating Method Using the Same to Form a Capacitor, U.S. Patent, July 1967.

[10] M.A. Paris, J. Sanz, C. León, J. Ibarra, A. Várez, Chem. Mater. 12 (2000) 1694-1701.

[11] M. Itoh, Y. Inaguma, W. Jung, L. Chen, T. Nakamura, Solid State Ionics 70/71 (1995) 203207.

[12] V.I. Thangadura, A.K. Shukla, J. Gopalakrishnan, Chem. Mater. 11 (1999) 835839.

[13] H. Watanabe, J. Kuwano, J. Power Sources. 68 (1997) 421-426.

[14] O.N. Gavrilenko, A.G. Belous, L.L. Kovalenko, Ye.V. Pashkova, Mater. Manuf. Processes 23 (2008) 607-610.

[15] A. Rivera, C. León, J. Santamaría, A. Várez, O. V'yunov, A. Belous, J. Alonso, J. Sanz, Chem. Mater. 14 (2002) 5148-5152.

[16] M. Sanjuan, M. Laguna, A. Belous, O. V'yunov, Chem. Mater. 17 (2005) 5862-5866.

[17] O. Bohnke, Solid State Ionics 179 (2008) 9-15.

[18] R. Jimene, A. Rivera, A. Várez, J. Sanz, Solid State Ionics 180 (2009) 1362-1371.

[19] T. Katsumata, Y. Inaguma, M. Itoh, Solid State Ionics 113-115 (1998) 465-469.

[20] Y. Jin Shan, N. Sinozaki, T. Nakamura, Solid State Ionics 108 (1998) 403-406.

[21] V.B. Nalbandyan, I.A. Shukaev, Zh. Neorg. Khim. 34 (1989) 793-795.

Proceeding of the XI International Conference on Crystal Chemistry of Intermetallic Compounds,

Lviv, May 30 - June 2, 2010. 